\title{
THE ROLE OF METALLURGICAL DEFECTS AND MICROSTRUCTURE ON FAILURE FORMATION IN ROLL NECKS OF CAST IRON ROLLS
}

\section{INTRODUCTION}

Metallurgical rolls are greatly subjected to failure in the roll neck - roll face contact areas, what results from the significant stress concentration in these areas [1]. Cast rolls are particularly subjected to such failures due to their low crack resistance [2-4]. This work presents the examples of structural reasons for failure of the necks of cast iron rolls.

\section{DAMAGED METALLURGICAL ROLLS}

For investigation of reasons for failure of rolls necks four rolls were chosen (Fig. 1). The chemical composition of the rolls is shown in Table 1. Roll No. 2 was made of cast iron with modular graphite, and rolls No. 1, 3, and 4 were made of cast iron containing flake graphite (Fig. 2). It should be noticed, that morphology of graphite precipitates in the case of the rolls No. 3 and 4 is different in the core of the roll neck than that in the vicinity of its surface (Figs. $2 c \div f$ ). It results from the conditions of crystallization. In the vicinity of the roll neck surface a banding character of graphite precipitates could be noticed (Figs. 2d, f).

Table 1. The chemical composition (weight \%) of the investigated rolls

\begin{tabular}{||c|c|c|c|c|c|c|c|c||}
\hline No. of roll & $\mathrm{C}$ & $\mathrm{Mn}$ & $\mathrm{Si}$ & $\mathrm{P}$ & $\mathrm{S}$ & $\mathrm{Cr}$ & $\mathrm{Ni}$ & $\mathrm{Mo}$ \\
\hline 1 & 3.27 & 0.81 & 0.96 & 0.07 & 0.025 & 0.95 & 1.15 & 0.25 \\
\hline 2 & 3.46 & 0.41 & 1.35 & 0.04 & 0.010 & 0.39 & 1.46 & 0.17 \\
\hline 3 & 3.50 & 0.74 & 1.22 & 0.06 & 0.023 & 1.37 & 1.23 & 0.32 \\
\hline 4 & 3.44 & 0.74 & 1.23 & 0.05 & 0.023 & 1.35 & 1.22 & 0.32 \\
\hline
\end{tabular}

* Ph.D.; Prof., D.Sc., Ph.D.: Faculty of Metals Engineering and Industrial Computer Science, AGH University of Science and Technology, Cracow, Poland; jkrawczy@metal.agh.edu.pl; pacyna@agh.edu.pl 
a)

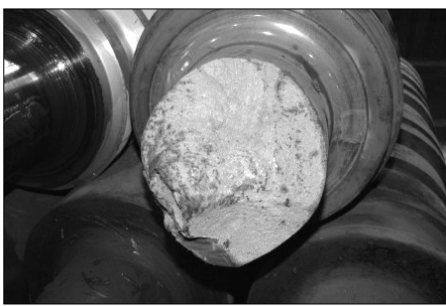

c)

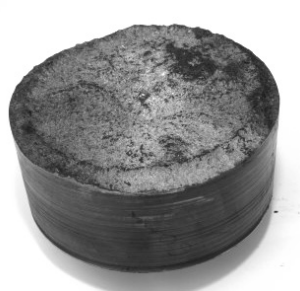

b)

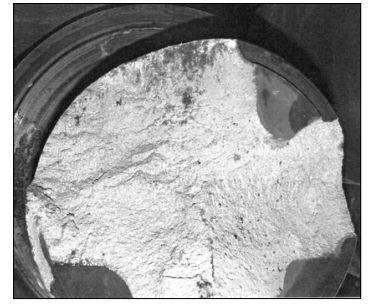

d)

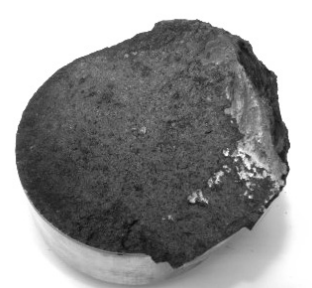

Fig. 1. Damaged roll necks: a) roll No. 1 after roll neck break off; b) roll No. 2 after roll neck break off; c) broken off part of the neck of the roll No. 3; d) broken off part of the neck of the roll No. 4

a)

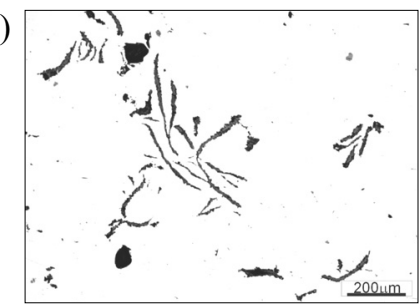

c)

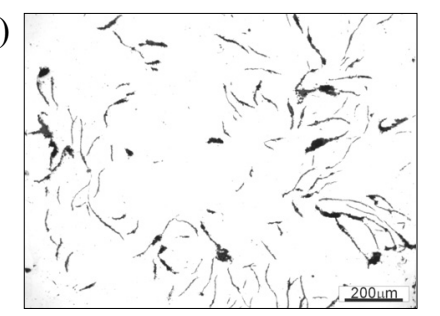

e)

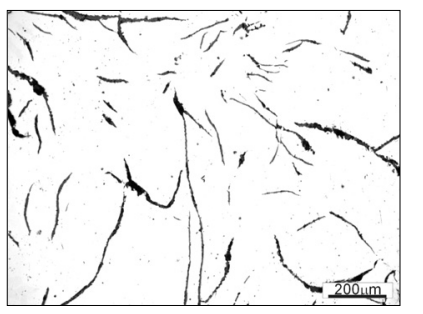

b)

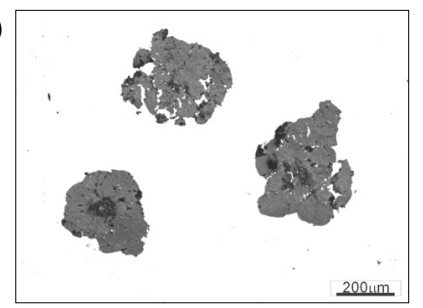

d)

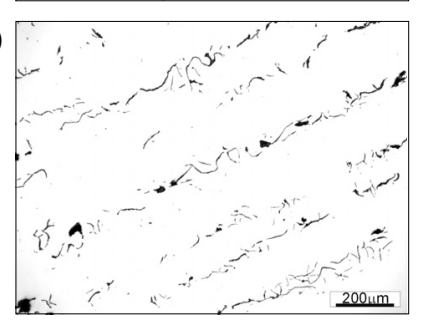

f)

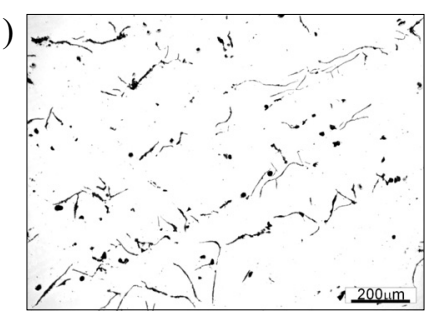

Fig. 2. Precipitates of graphite in investigated rolls: a) roll No. 1; b) roll No. 2; c) roll No. 3 (precipitates of graphite in the core of the roll neck); d) roll No. 3 (precipitates of graphite near the surface of the roll neck); e) roll No. 4 (precipitates of graphite in the core of the roll neck); f) roll No. 4 (precipitates of graphite near the surface of the roll neck) 
a)

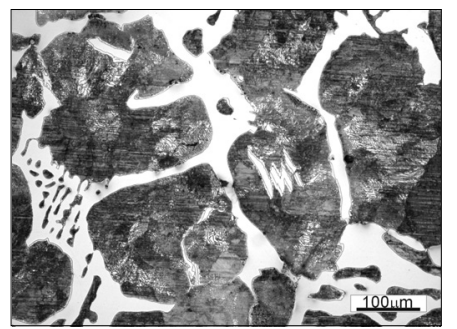

c)

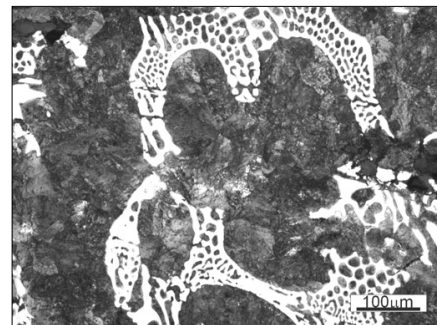

e)

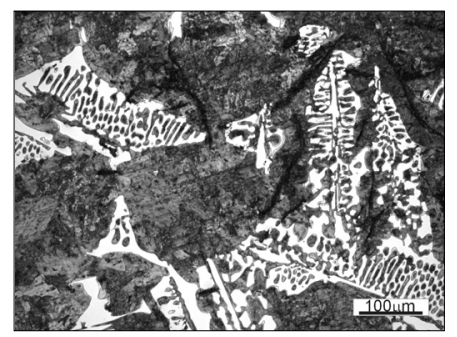

b)

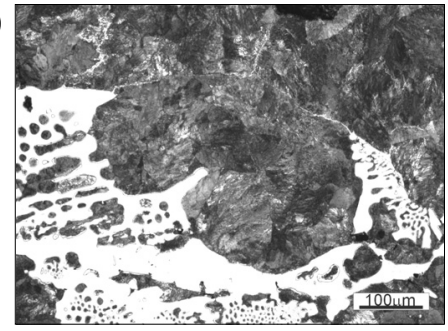

d)

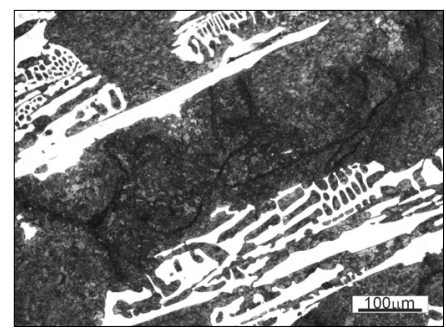

f)

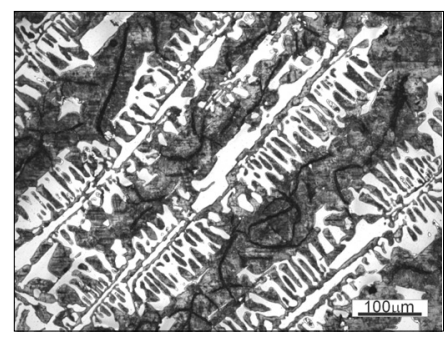

Fig. 3. Microstructure of investigated rolls: a) roll No. 1, b) roll No. 2, c) roll No. 3 (core of the roll neck), d) roll No. 3 (near the surface of the roll neck), e) roll No. 4 (core of the roll neck), f) roll No. 4 (near the surface of the roll neck). Etched with $2 \%$ nital

The microstructure of investigated rolls was shown in Figure 3. In the microstructure of all investigated rolls transformed ledeburite as well as pearlite could be observed. It should also be noticed, that volume fraction of hard, but also brittle ledeburitic cementite is high in the case of rolls No. 1 , No. 3 , and No. 4. Besides, it forms a continuous net, which is unfavorable from the mechanical properties point of view. As can be seen, precipitations of transformed ledeburite (originally ledeburite, so eutectic mixture) and flake graphite in the vicinity of the roll neck of rolls No. 3 and No. 4 exist in a form of bands. The conditions of crystallization of the roll neck influenced such banding of its structure. Originally, dendritic crystals were formed on the surfaces, in which the flakes of graphite were precipitating, and then quasieutectic (ledeburite) precipitated out of remaining mixture.

\section{METALLURGICAL DEFECTS}

The most common reason for defects in roll necks is a presence of shrinkage porosity in their interior. In the case of investigated (damaged) roll necks, the areas of shrinkage porosity were detected in roll No. 1 and roll No. 2, what was shown in Figure 4. As can be seen, the pores are distributed in the areas where eutectic should exist. Such porosity is most common place of crack nucleation. Then, these cracks propagate along brittle carbide 
phase, neighbouring with shrinkage porosity. These cracks propagate from the core of the roll neck (areas, where shrinkage porosity exists), along the maximum sheer stresses (acting during roll bending) towards the roll face (Fig. 1a, b). Such character of a damage of the roll neck should always lead to investigation of metallurgical faults inside the roll neck core, as the most probable reasons for damage formation. It is worth to notice, that shrinkage porosity forms particularly easy in the upper part of the casting, what should be taken into account while choosing which roll neck should be placed on the side of the roll drive.

a)

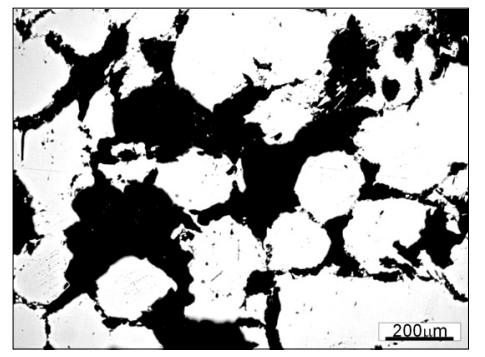

c)

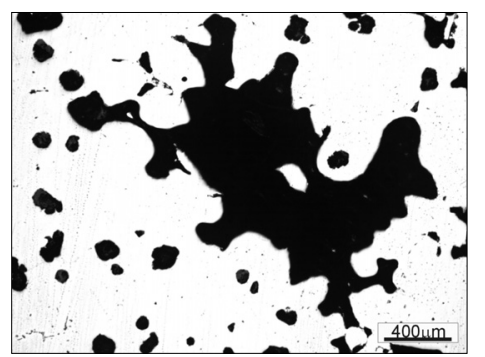

b)

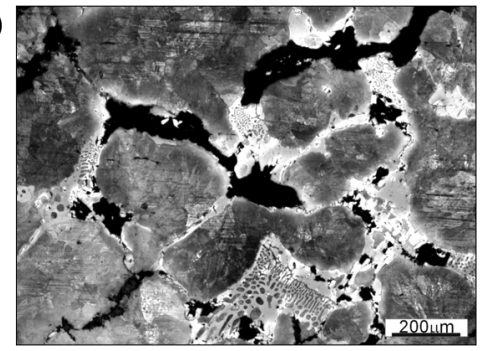

d)

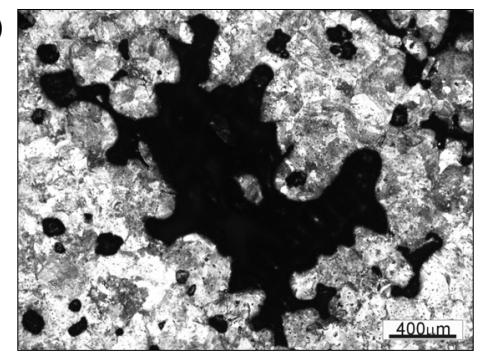

Fig. 4. Shrinkage porosity area: a) roll No. 1 (unetched cross-section); b) roll No. 1 (etched crosssection); c) roll No. 2 (unetched cross-section); d) roll No. 2 (area from Fig. 4c after etching). Etched with $2 \%$ nital

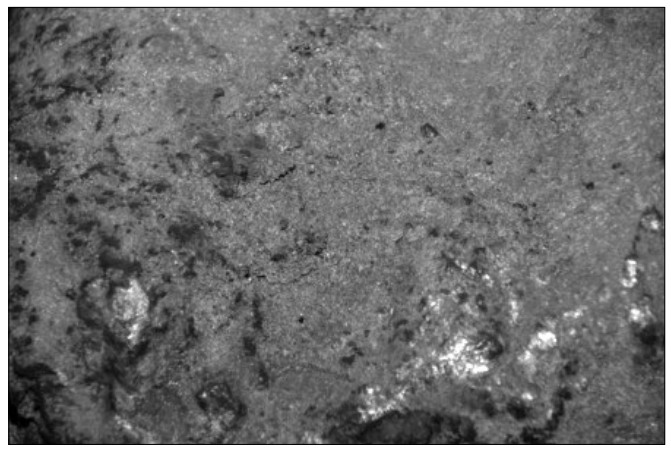

Fig. 5. The area of shrinkage porosity on fracture surface of the roll No. 1

Macroscopic observations of the roll neck can also allow identifying the shrinkage porosity. Figure 5 shows the fracture surface of the roll No. 1, where shrinkage porosity can be noticed. 


\section{THE ROLE OF THE MORPHOLOGY OF TRANSFORMED LEDEBURITE}

In the microstructure of almost all rolls (except roll No. 2), continuous net of ledeburitic cementite exists (with cementite built up on it, precipitated from austenite in the result of decreasing solubility of carbon in austenite ongoing with a decrease of the temperature). This continuous net of ledeburitic cementite facilitates crack propagation (Fig. 6). In the case when precipitates of ledeburite are in a form of bands, cracks will propagate along these bands (Fig. 7). If stresses cause different than parallel to these bands direction of cracking, then cracking will propagate by "jumping" over from one band to another through "cementite bridges" between them (Fig. 8).

a)

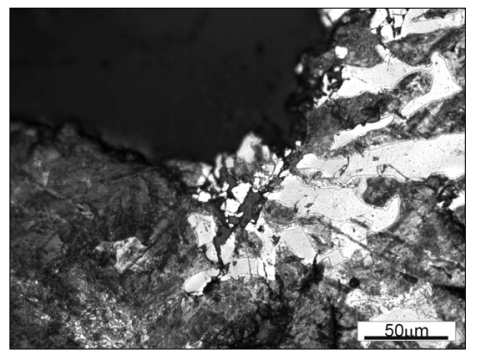

b)

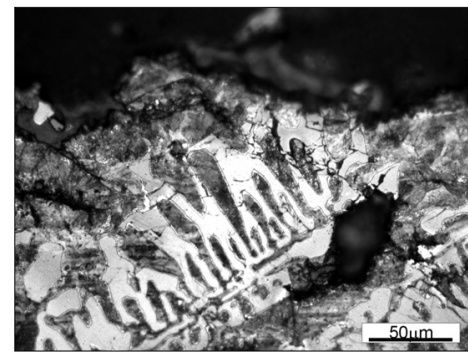

Fig. 6. Fracture propagating through the precipitates of ledeburitic cementite (roll No. 4): a) selected area; b) second selected area. Etched with $2 \%$ nital

a)

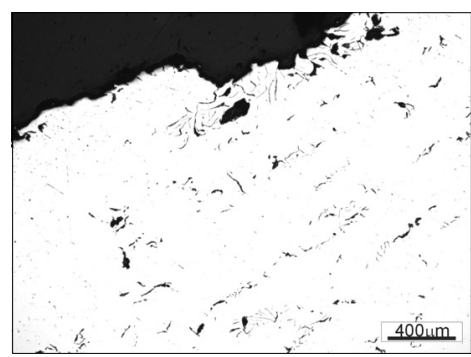

b)

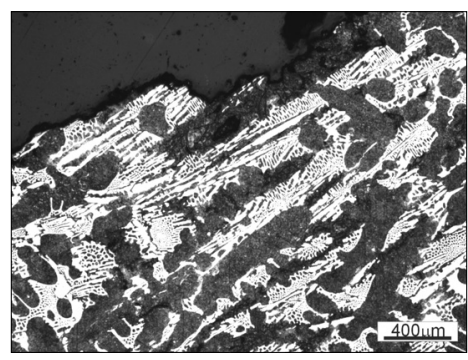

Fig. 7. Fracture propagating along ledeburitic cementite bands (roll No. 3): a) unetched cross-section; b) area from Fig a after etching. Etched with $2 \%$ nital

a)

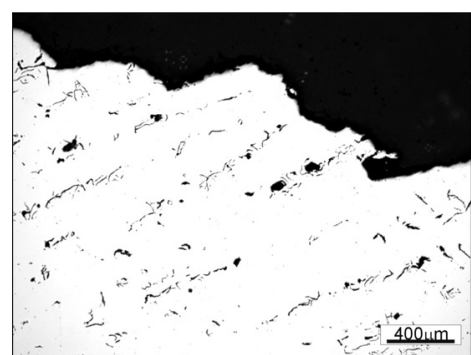

b)

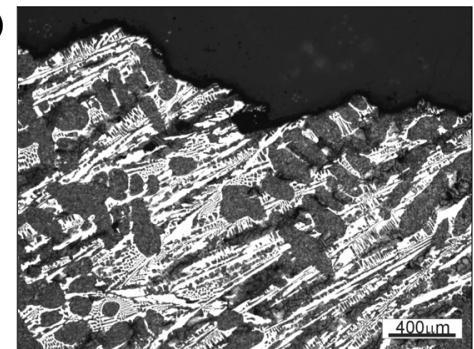

Fig. 8. A profile of the fracture in the surface area of damaged neck of the roll No. 3: a) unetched cross-section; b) area from Fig. a after etching. Etched with $2 \%$ nital 
Described above disadvantageous morphology of transformed ledeburite was the reason for failure of the rolls No. 3 and No. 4 (see Figs. 1c, and 1d), but shrinkage porosity was not observed in their microstructure. The way of development of original fatigue crack was mostly influenced by the state of sheer stresses in the neck of these rolls. That is why in roll No. 3 the crack propagates to a depth of about $15 \mathrm{~mm}$ by "jumping" over from one band of ledeburite to another. When this fatigue crack reached the critical length, the microstructure (banding) had predominant influence on its development. Similar mechanisms were observed in the case of the roll No. 4 with this only difference that initial crack developed only on one side of the roll neck (see Figs. 1c and 1d).

\section{THE ROLE OF THE MORPHOLOGY OF SECONDARY CEMENTITE}

Secondary cementite in mottled cast irons can build itself on the net of transformed ledeburite, but it can also occur as independent component of the structure. Considering crack resistance, the most disadvantageous is precipitation of such cementite along grain boundaries of austenite. In the case of the roll No. 2 secondary cementite precipitated in a form of very thin, continuous net along austenite grain boundaries (Fig. 9).

a)

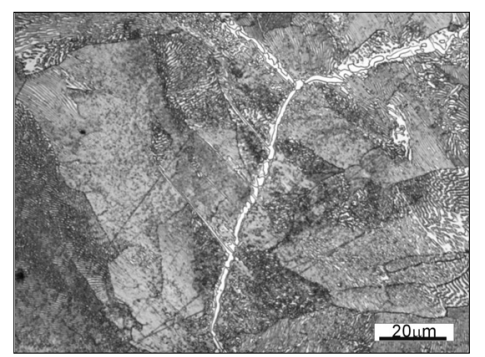

b)

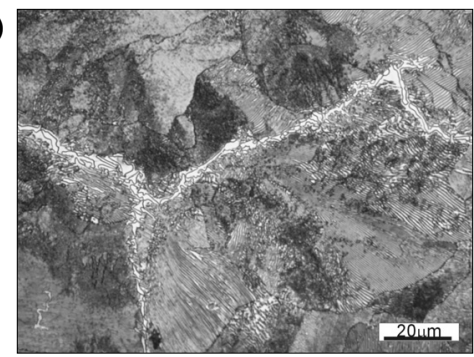

Fig. 9. Continuous net of secondary cementite precipitated along boundaries of former grain of austenite in the structure of the neck of roll No. 2: a) selected area; b) second selected area. Etched with $2 \%$ nital

a)

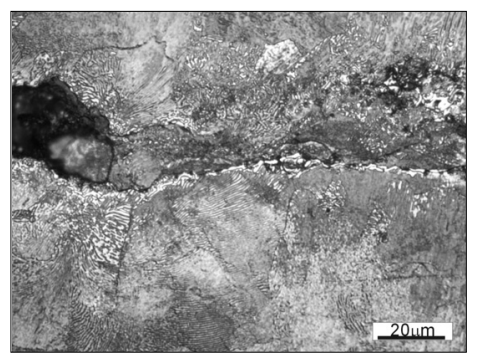

b)

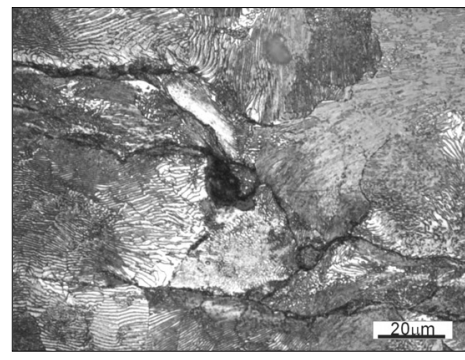

Fig. 10. Development of the crack along continuous thin net of secondary cementite (roll No. 2): a) selected area; $b)$ second selected area. Etched with $2 \%$ nital

Even so thin net of secondary cementite significantly facilitates propagation of the crack (Fig. 10). This thin net of secondary cementite combined with shrinkage porosity became a reason for damage of the neck of the roll No. 2 . 


\section{THE ROLE OF THE GRAPHITE MORPHOLOGY}

In the case of cast iron, the morphology of graphite precipitates can have a strong influence on their crack resistance. In this respect, the most favorable is his spheroidal form, less advantageous is vermicular, and the least favorable is a flake form [5]. The most unfavorable case occurs, when the bands of flake graphite precipitates exist in the structure, as it was revealed in the surface area of the neck of rolls No. 3 and No. 4. It is due to the fact, that graphite precipitates are practically incapable of transmitting stresses, thus they can be considered as voids.

Spheroidal precipitates of graphite can even restrict crack propagation, causing its "blunting". However, flaky precipitates can act as crack nucleuses, forming so called structural notches.

In the microstructure of rolls No. 3 and No. 4, flake graphite precipitates facilitated crack migration from one band of transformed ledeburite to another (Fig. 8). The bands of flake graphite precipitates also formed the paths for crack development (Figs. 7 and 11).

a)

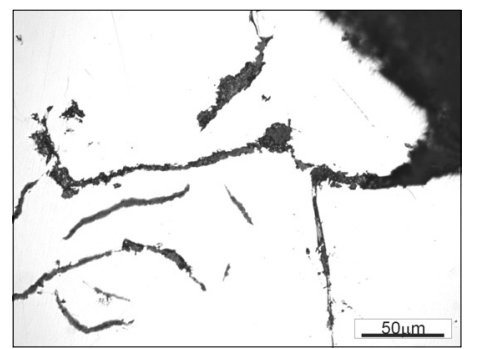

b)

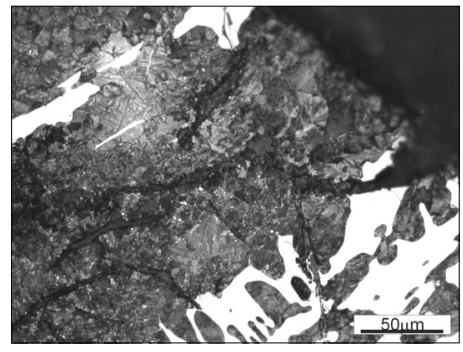

Fig. 11. Contribution of flake graphite precipitates in crack development (roll No. 3): a) unetched cross-section; b) area from Fig. a after etching. Etched with $2 \%$ nital

\section{SUMMARY}

The following conclusions can be driven from this study:

1. The most common reason for damage of metallurgical roll necks is a presence of shrinkage porosity in their volume.

2. Increasing hardness of cast iron rolls by adding carbide-forming elements causes an increase of brittle eutectic mixture fraction in the structure of roll neck (an increase of ledeburitic cementite fraction - so called "hard spots").

3. A high fraction of ledeburitic cementite can lead to the formation of a continuous net of eutectic carbides, which facilitate cracking.

4. Even very thin net of secondary carbides, formed on the boundaries of former grain of austenite, can significantly facilitate propagation of the crack.

5. The conditions of crystallization of cast iron rolls favor precipitating of ledeburitic cementite in a form of bands especially in vicinity of roll neck surface.

6. Continuous net of ledeburitic cementite, in the case of its precipitation in a form of bands and existence of hardened areas in the alloy matrix can lead to roll neck fracture relatively easy. 
7. The use of flake graphite cast iron for metallurgical rolls increases a risk of the fracture of roll neck. In rugged working conditions (for example strong bending of rolls), spheroidal or vermicular graphite cast iron should be used, which is more crack resistant [5].

\section{REFERENCES}

[1] Pacyna J.: Wybrane problemy materiałowe i eksploatacyjne walców hutniczych. III Konferencja Naukowa: Walcownictwo 2005: Procesy-Narzędzia-Materiały, Ed. Andrzej Nowakowski, Ustroń, 19 21 październik $2005,49 \div 60$

[2] Pacyna J., Krawczyk J., Zajac G.: Nowa technologia obróbki cieplnej żeliwa sferoidalnego chromowo niklowego. IX Konferencja Naukowo-Techniczna, 120 lat Huty Buczek S.A. „Kierunki rozwoju produkcji

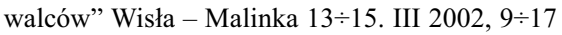

[3] Krawczyk J., Pacyna J., Kokosza A.: Fracture toughness of cast materials for mill rolls. Proceedings of the $6^{\text {th }}$ International Conference for Mesomechanics, Multiscaling in Applied Science and Emerging Technology, Fundamentals and Applications in Mesomechanics, 31 May $\div 4$ June, 2004, Patras, Greece, p. $203 \div 207$

[4] Głownia J.: Rola segregacji w procesie pękania walców staliwnych. Zeszyty Naukowe AGH nr 1163, Me-

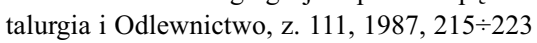

[5] Guzik E.: Procesy uszlachetniania żeliwa, wybrane zagadnienia. Archiwum Odlewnictwa, Monografia nr 1M, 2001

Received

August 2007 